\title{
History, narration and experience in medicine
}

José Luis Sandoval-Gutiérrez

Secretaría de Salud, Instituto Nacional de Enfermedades Respiratorias Ismael Cosío Villegas, Pulmonology Department, Ciudad de México, Mexico

Doctor Rodríguez de Romo, in her editorial article "History of medicine is a science"1 mentions the news that Gaceta Médica de México is going to include contributions about history of medicine as original articles, with the purpose to empower this type of articles. She refers the traditional form medical and clinical researchers have considered the history of medicine discipline: more in the field of narration and experiential account, without appreciating the scientific rigor required to contribute with data and dates in the documents.

In Mexico, there is a documentary deficit in all areas of knowledge. In other disciplines, the need for a law of archives to be updated has been addressed, and this has recently been voted by the Senate, ${ }^{2}$ since a society with no history is a society without memory.
It is important for medical experiential accounts to be considered for publication in this important source of dissemination of the Academy, since with no doubt they are highly educational for clinicians; perhaps, opening a narrative medicine ${ }^{3}$ section in order to include them should be considered.

I congratulate myself, as doctor Rodríguez de Romo does, for this decision of the Gaceta editorial board.

\section{References}

1. Rodríguez-De Romo AC. La historia de la medicina es una ciencia. Gac Med Mex. 2018;154:5-7.

2. Senado de la República. Proyecto de decreto por el que se expide la Ley General de Archivos. México: Senado de la República; 2017.

3. Narrative medicine [sitio web]. Disponible en: http://sps.columbia.edu/ narrative-medicine/faculty/rita-charon.
Gac Med Mex. 2018;154:292-292

Contents available at PubMed www.gacetamedicademexico.com 